\title{
Studi Bioekologi Vektor Malaria di Daerah (Yang Mendapat Sertifikat) Eliminasi Malaria di Kabupaten Jembrana, Bengkalis dan Bulukumba
}

\author{
ECOLOGY OF MALARIA VECTORS IN CERTIFIED MALARIA ELIMINATION AREAS IN \\ JEMBRANA, BENGKALIS AND BULUKUMBA DISTRICTS
}

\author{
Riyani Setiyaningsih ${ }^{1 *}$, Ary Oktsari Yanti, Mega Tyas Prihatin, Arif Suryo Prasetyo, Sidiq Setyo \\ Nugroho, Yusnita Mirna Anggraeni, Wiwik Trapsilowati, dan Triwibowo Ambar Garjito \\ ${ }^{1}$ Balai Besar Penelitian dan Pengembangan Vektor dan Reservoir Penyakit Salatiga \\ Jl. Hasanudin no. 123 Salatiga Indonesia \\ *Email : riyanisetia@gmail.com@email.com
}

Submitted:05-08-2019, Revised:14-10-2019, Revised:12-11-2019, Accepted : 28-11-2019

\begin{abstract}
The target of malaria elimination in Indonesia is expected to be achieved in 2030. One of the activities to support malaria elimination is vector surveillance. Several districts in Indonesia have certificates of malaria, including Jembrana, Bali Province, Bulukumba, South Sulawesi Province, and Bengkalis, Riau Province. Analysis of the presence of malaria vectors and Plasmodium needs to be done for the potential occurances of malaria transmission in eliminated malaria areas. Bioecology study of malaria vectors were conducted to determine receptivity status and others risk factors and the potential for malaria transmission based on ecosystems in Jembrana, Bulukumba and Bengkalis districts. As part of national research of disease vector and reservoir (Rikhus Vektora), mosquitoes and larval field-collection methods, molecular plasmodium detection and blood meal analyses were carried out according Rikhus vektora guidelines. The result showed that Anopheles kochi and An. tesselatus were positive confirmed with Plasmodium falciparum by using PCR in Jembrana, Bali province, which were found in non-forest ecosystems near settlements and beaches near settlements. In addition, Anopheles barbirostris, Anopheles vagus, and Anopheles peditaeniatus were also positive confirmed with P. falciparum by using similar methods in Bulukumba, South Sulawesi province. An. barbirostris was found in forest ecosystems near settlement, Anopheles vagus was found in remote forest ecosystems of settlements and beaches near settlements, and Anopheles peditaenistus was found in non-forest ecosystems near settlements. While Anopheles sinensis was confirmed positive with P. falciparum in Bengkalis, Riau province. Jembrana, Bulukumba and Bengkalis districts are recognized as receptive areas and have potential for re-transmission of malaria. Vector surveillance and the implementation of approriate vector control and migration surveillance are needed to ascertain wheter the positive Anopheles with positives Plasmodium falciparum getting the parasites from imported cases or there has been a local transmission (indigenous) in these areas. This information is needed to prevent malaria re-transmission in the eliminated areas.
\end{abstract}

Keywords : elimination, malaria, vector

\begin{abstract}
Abstrak
Target eliminasi malaria di Indonesia harapannya dapat dicapai tahun 2030. Salah satu kegiatan yang dilakukan untuk menunjang elimnasi malaria adalah surveilans vektor. Beberapa Kabupaten di Indonesia telah memperoleh serfikat eliminasi malaria diantaranya Kabupaten Jembrana Propinsi Bali, Bulukumba Propinsi Sulawesi Selatan, dan Bengkalis Propinsi Riau. Analisis keberadaan vektor dan patogen malaria perlu dilakukan untuk melihat potensi terjadinya penularan malaria kembali di daerah yang telah mendapatkan sertifikat eliminasi malaria. Studi bioekologi vektor malaria dilakukan untuk mengetahui status reseptivitas dan faktor risiko lainnya, serta potensi penularan malaria berbasis ekosistem di daerah tersebut. Sebagai bagian dari dari Riset khusus
\end{abstract}


(rikhus) vektora, koleksi lapangan nyamuk dan jentik, prosedur deteksi melekuler plasmodium dan analisis pakan darah dilakukan dengan menggunakan pedoman Rikhus vektora. Hasil studi menunjukkan bahwa Anopheles kochi dan Anopheles tesselatus, yang masing-masing ditemukan di eksoistem non hutan dekat pemukiman dan pantai dekat pemukiman ditemukan positif mengandung Plasmodium falciparum di Kabupaten Jembrana, Bali. Sedangkan di Kabupaten Bulukumba, Sulawesi Selatan, Anopheles barbirostris, Anopheles vagus, dan Anopheles peditaeniatus merupakan spesies Anopheles yang terkonfirmasi positif mengandung P. falciparum. An. barbirostris ditemukan di ekosistem hutan dekat pemukiman, Anopheles vagus ditemukan di ekosistem hutan jauh pemukiman dan pantai dekat pemukiman, dan Anopheles peditaenistus ditemukan di ekosistem non hutan dekat pemukiman. Sedangkan Anopheles sinensis merupakan satu-satunya spesies Anopheles yang ditemukan positif mengandung P. falciparum di Kabupaten Bengkalis, Riau. Dari hasil studi menunjukkan, Kabupaten Jembrana, Bulukumba, dan Bengkalis merupakan daerah reseptif dan berpotensi terjadinya penularan kembali malaria. Surveilans vektor dan implementasi pengendalian vektor yang tepat serta surveilans migrasi secara ketat diperlukan untuk memastikan apakah Anopheles yang positif tersebut mendapatkan parasit $P$. falciparum dari kasus import ataukah memang sudah terjadi transmisi secara lokal (indigenous) di wilayah tersebut. Hal ini perlu dilakukan agar tidak terjadi penularan kembali malaria di daerah yang sudah tereliminasi tersebut.

Kata kunci :eliminasi, malaria, vektor

\section{PENDAHULUAN}

Kemajuan teknologi dewasa ini Eliminasi malaria menjadi isu global pada pertemuan World health assembly (WHA) ke 60 di Geneva. Berdasarkan komitmen regional (Asia Pasific Malaria Network/APMEN) tahun 2014 diharapkan eliminasi malaria di kawasan Asia Pasifik dapat dicapai pada tahun 2030. ${ }^{1,2}$ Sampai dengan tahun 2016, beberapa provinsi di Indonesia telah mendapatkan sertifikat eliminasi malaria, diantaranya adalah DKI Jakarta dan Bali. Meskipun demikian, proses mendapatkan status eliminasi malaria di setiap kabupaten/kota berbeda di masing-masing provinsi. ${ }^{3}$

Status daerah eliminasi malaria tersebut perlu dipertahankan agar tidak terjadi penularan malaria kembali. Dalam rangka mempertahankan sebagai daerah eliminasi malaria, upaya pencegahan perlu dilakukan dengan melakukan kegiatan surveilans secara aktif terhadap berbagai faktor risiko penularan. ${ }^{2}$ Salah satu diantaranya adalah survelans vektor malaria., ${ }^{1,2}$

Secara global, surveilans vektor malaria menjadi strategi utama di semua negara yang rentan dan reseptif terhadap malaria, termasuk negara yang telah mengalami eliminasi namun rentan terjadi penularan kembali. Tujuan pelaksanaan surveilans vektor malaria menurut World Health Organization (WHO) adalah:1.
Untuk menentukan karakterisasi daerah reseptif yang digunakan untuk seleksi dan stratifikasi dalam intervensi pengendalian vektor, 2. Untuk mengetahui kepadatan vektor malaria yang diperlukan dalam menentukan waktu pengendalian vektor yang tepat berdasarkan musim penularan, 3. Untuk memonitor terjadinya resistensi insektisida, 4. Untuk mengidentifikasi potensi kegagalan pengendalian vektor, dan 5. Untuk mengidentifikasi kesenjangan dalam cakupan intervensi pengendalian vektor. ${ }^{4}$

Untuk mencapai tujuan tersebut, diperlukan beberapa indikator yang menjadi dasar pelaksanaan surveilans vektor yang diharapkan, yaitu identifikasi vektor, densitas vektor, perilaku mencari darah, kesukaan menggigit di dalam/di luar rumah, kesukaan istirahat di dalam/di luar rumah, konfirmasi Plasmodium dalam nyamuk vektor dan habitat larva vektor, disamping hasil konfirmasi resistensi insektisida. Dengan mengintegrasikan indikator tersebut, diharapkan dapat digunakan untuk menetapkan strategi dan perencanaan pengendalian vektor sehingga diharapkan upaya pengendalian vektor dapat dilakukan secara efektif dan efisien. ${ }^{4}$

Pada tahun 2017 Balai Besar Litbang Vektor dan Reservoir Penyakit (B2P2VRP), Badan Penelitian dan Pengembangan Kesehatan (Badan Litbangkes) melakukan Riset Khusus Vektor dan Reservoir Penyakit (Rikhus 
Vektora) di 7 wilayah provinsi di Indonesia. Di setiap provinsi tersebut, dipilih 3 kabupaten sebagai wilayah penelitian berdasarkan kriteria endemisitas penyakit tular vektor dan reservoir. ${ }^{5}$ Kabupaten Jembrana, Bulukumba dan Bengkalis merupakan 3 lokasi terpilih dalam studi ini. Ketiga kabupaten tersebut juga dilaporkan telah mendapatkan sertifikat eliminasi malaria bersama dengan 245 kabupaten/kota lainnya pada tahun 2016 .

Sehubungan dengan hal tersebut, studi bioekologi vektor malaria dilakukan sebagai bagian dari Rikhus Vektora di ketiga wilayah kabupaten tersebut untuk mengetahui status reseptivitas dan faktor risiko lainnya, serta potensi penularan malaria berbasis ekosistem di daerah tersebut. Hasil studi ini diharapkan dapat dimanfaatkan sebagai tindak lanjut rekomendasi surveilans vektor di daerah endemis malaria yang sudah tereliminasi untuk mendukung target eliminasi malaria pada tahun 2030 di Indonesia.

\section{BAHAN DAN METODE}

Penelitian ini merupakan bagian dari Riset Khusus Vektor dan Reservoir Penyakit yang dilakukan di tujuh propinsi pada tahun 2017. Penggunaan data telah mendapat ijin dari laboratorium manajemen data Badan Litbangkes berdasarkan surat persetujuan no: 4/3/2019/ TU:21/3/2019, pada tanggal 25 Maret 2019. Seluruh penentuan lokasi, metode pengambilan data dan analisis berdasarkan pada pedoman pengumpulan data vektor dan deteksi laboratorium Rikhus Vektora. ${ }^{5,13}$ Lokasi pengambilan sampel dilakukan di Kabupaten Jembrana Bali, Kabupaten Bulukumba Sulawesi Selatan dan Kabupaten Bengkalis Riau. Sampel diambil pada enam titik berdasarkan perbedaan tipe ekosistem di masing-masing kabupaten yaitu ekosistem hutan dekat pemukiman (HDP), hutan jauh pemukiman (HJP), non hutan dekat pemukiman (NHDP), non hutan jauh pemukiman (NHJP), pantai dekat pemukiman (PDP), dan pantai jauh pemukiman (PJP). Lokasi pengambilan sampel secara lengkap dapat dilihat pada tabel 1 .
Tabel 1.Lokasi pengambilan sampel di Kabupaten Bulukumba, Bengkalis dan Jembrana tahun 2017.6,7,

\begin{tabular}{llll}
\hline Kabupaten & Ekosistem & Kecamatan & \multicolumn{1}{c}{ Desa } \\
\hline \multirow{6}{*}{ Jembrana } & HDP & Pekutatan & Manggissari \\
& HJP & Jembrana & Batuagung \\
& NHDP & Melaya & Ekasari \\
& PDP & Melaya & Warnasari \\
& PJP & Melaya & Candikesuma \\
& HDP & Kindang & Gilimanuk \\
& HJP & Kindang & Borong Rappoa \\
& NHDP & Gantaarag & Palambarae \\
& NHJP & Ujung Loe & Tamatto \\
& PDP & Bonto Bahari & Tanah Lemo \\
& PJP & Bonto Bahari & Tanah Lemo \\
& HDP & Pinggir & Tasik Serai \\
& HJP & Pinggir & Tasik Serai \\
& NHDP & Bukitbatu & Bukit Kerikil \\
& NHJP & Bukitbatu & Bukit Kerikil \\
& PDP & Bukitbatu & Sungai Pakning \\
& PJP & Bukitbatu & Sepahat \\
\hline \multirow{6}{*}{ Bengkalis } & &
\end{tabular}

Keterangan:

HDP : hutan dekat pemukiman

HJP : hutan jauh pemukiman

NHDP : non hutan dekat pemukiman

NHJP : non hutan jauh pemukiman

PDP : pantai dekat pemukiman

PJP : pantai jauh pemukiman

Pengambilan sampel di tiap titik dilakukan selama lima hari dengan kegiatan meliputi koleksi nyamuk dan preparasi sampel untuk deteksi Plasmodium, survei jentik serta lingkungan tempat perkembangbiakannya. Penangkapan nyamuk dilakukan dengan menggunakan lima metode yaitu human landing collection, Animal-Baited Trap (ABT), umpan ternak (UT), penangkapan nyamuk pagi hari / morning resting (MR), dan light trap (LT). Secara keseluruhan, survey dilaksanakan selama 1 bulan (masing-masing 5 hari di 6 lokasi). Waktu pengambilan sampel dilakukan pada tanggal 25 April sampai 25 Mei 2017.

Penangkapan dengan metode human landing collection dilakukan dengan umpan orang di luar rumah (UOL) dan umpan orang di dalam rumah (UOD). Penangkapan nyamuk dilakukan di enam rumah yang berbeda. Kegiatan penangkapan nyamuk dilakukan dari mulai pukul 18.00 sampai dengan pukul 06.00. Lama penangkapan nyamuk di setiap jamnya adalah 50 menit umpan orang (baik di dalam maupun di luar rumah), dan 10 menit istirahat. ${ }^{5,9}$ 
Penangkapan nyamuk dengan ABT dilakukan dengan memasang ABT di tanah lapang. Ternak dimasukkan di dalam ABT sebelum jam 18.00 dengan cara mengikatnya pada tonggak kayu. Ternak yang digunakan dapat berupa sapi atau kerbau. Jika tidak ada ternak besar dapat menggunakan kambing dua ekor. ${ }^{5,9}$ Penangkapan nyamuk di ABT dilakukan pada jam 18.00-06.00 dengan lama penangkapan tiap jamnya adalah 15 menit. ${ }^{5,9}$

Penangkapan nyamuk istirahat pagi hari dilakukan pada pukul 06.00-09.00 di tempat-tempat yang berpotensi sebagai tempat peristirahatan nyamuk. Beberapa tempat yang disurvei antara lain tebing sungai, akar tanaman, semak-semak dan lainnya. Penangkapan nyamuk dilakukan dengan menggunakan aspirator dan jaring nyamuk. ${ }^{5,9}$

Penangkapan nyamuk dengan light trap dilakukan pada jam 18.00-06.00. Light trap di gantungpada dahan pohon dengan ketinggian $\pm 1,5$ meter dari tanah. Pemasangan light trap dilakukan di tempat-tempat dekat perkembangbiakan nyamuk dan jauh dari jangkauan orang. Lampu dan dry ice digunakan sebagai attractant nyamuk. Pengambilan sampel nyamuk dilakukan pagi hari pada akhir penangkapan nyamuk. ${ }^{5,9}$

Survei jentik dilakukan di tempat yang berpotensi sebagai tempat perkembangbiakan nyamuk vektor malaria antara lain sawah, lagun, tambak, kobakan di sekitar sungai dan lainnya. Jentik nyamuk diambil dengan menggunakan cidukan jentik. Jentik hasil koleksi dipelihara sampai menjadi nyamuk dewasa kemudian diidentifikasi spesiesnya. Nyamuk Anopheles hasil pemeliharaan dari jentik dibuat sebagai spesimen awetan nyamuk.

Hasil penangkapan nyamuk dengan berbagai metode tersebut kemudian diidentifikasi spesiesnya dengan menggunakan kunci identifikasi nyamuk. ${ }^{10,11,12}$ Terhadap nyamuk Anopheles yang tertangkap $10 \%$ dijadikan sebagai spesimen awetan dan 90\% digunakan untuk deteksi Plasmodium. Proses deteksi Plasmodium dilakukan dengan memotong kepala dan thorax kemudian dimasukkan ke dalam vial dan disimpan untuk dideteksi keberadaan Plasmodium di laboratorium Balai Besar Penelitian dan Pengembangan Vektor dan Reservoir Penyakit (B2P2VRP) Salatiga. Proses ekstraksi DNA dari nyamuk sampel dilakukan dengan dengan prosedur ekstraksi Dneasy Blood \& tissue kits Qiagen ${ }^{\circledR}$. Sedangkan proses deteksi Plasmodium secara molekuler dengan menggunakan metode nested polymerase chain reaction (Nested-PCR) dengan mengikuti protokol menurut Singh, et al. menggunakan primer rPLU1 (TCA AAG ATT AAG CCA TGC AAG TGA), rPLU5 (CCT GTT GTT GCC TTA AAC TCC), rPLU3 (TTT TTA TAA GGA TAA CTA CTA CGG AAA AGC TGT), rPLU4 (TAC CCG TCA TAG CCA TGT TAG GCC AAT ACC). Amplifikasi tahap pertama dilakukan dengan pre-denaturasi $94^{\circ} \mathrm{C}$ selama 4 menit, denaturasi $\left(94^{\circ} \mathrm{C}\right.$ selama 30 detik), annealing $\left(55^{\circ} \mathrm{C}\right.$ selama 1 menit $)$ dan extention $\left(72^{\circ} \mathrm{C}\right.$ selama 1 menit) selama 35 siklus, serta final extention $\left(72^{\circ} \mathrm{C}\right.$ selama 4 menit) dan hold $\left(12^{\circ} \mathrm{C}\right.$ selama $\left.\infty\right)$. Tahap kedua dilakukan dengan pre-denaturasi $94^{\circ} \mathrm{C}$ selama 4 menit, denaturasi $\left(94^{\circ} \mathrm{C}\right.$ selama 30 detik), annealing $\left(62^{\circ} \mathrm{C}\right.$ selama 1 menit) dan extention $\left(72^{\circ} \mathrm{C}\right.$ selama 1 menit $)$ selama 35 siklus, serta final extention $\left(72^{\circ} \mathrm{C}\right.$ selama 4 menit $)$ dan hold $\left(12^{\circ} \mathrm{C}\right.$ selama $\left.\infty\right)$. Sampel dinyatakan positif setelah dilakukan elektroforesis $1,5 \%$ dan muncul pita dengan target 240bp. ${ }^{13,14,15}$ Uji pakan darah juga dilakukan dengan menggunakan ELISA untuk mengetahui preferensi menghisap darah ternak/manusia.

Analisis hasil dilakukan secara diskriptif untuk melihat spesies dan distribusi nyamuk tertangkap pada berbagai metode penangkapan dan tipe ekosistem. Fluktuasi kepadatan nyamuk tertangkap dengan berbagai metode selama waktu penangkapan dan frekuensi nyamuk terkonfirmasi positife Plasmodium dengan metode PCR juga didiskripsikan.

\section{HASIL}

Berdasarkan hasil penangkapan nyamuk di Kabupaten Jembrana, An. vagus, $A n$. tesselatus, An. barbumbrosus, An. maculatus, An. barbirostris, An. subpictus, An. indefinitus, dan An. sundaicus berhasil dikoleksi dengan menggunakan umpan manusia, baik di dalam maupun di luar rumah. Spesies lainnya yang ditemukan di wilayah ini adalah An. kochi dan An. annularis. Distribusi spesies Anopheles yang tertangkap di Kabupaten Jembrana pada berbagai tipe ekosistem dapat dilihat pada 
Tabel 2. Hasil pemeriksaan pakan darah dari nyamuk yang tertangkap, $12,5 \% \mathrm{An}$. tesselatus teridentifikasi menghisap darah manusia, sedangkan An. kochi 100\% menghisap darah ternak. Sebanyak 3,6\% dari nyamuk An. vagus yang tertangkap teridentifikasi menghisap darah manusia dan sebanyak 75\% dari An. sundaicus yang tertangkap menghisap darah manusia. Sedangkan An. maculatus hanya ditemukan menghisap darah manusia (Tabel 2).

Hasil penangkapan nyamuk di Kabupaten Jembrana menunjukkan bahwa kepadatan Anopheles berfluktuasi dari pukul 18.0006.00 berdasarkan masing-masing spesies. Kepadatan dominan ditemukan pada An. vagus yang ditemukan pada setiap jam penangkapan. Fluktuasi kepadatan nyamuk pada masingmasing spesies secara keseluruhan dapat dilihat pada Gambar 1. Hasil pemeriksaan PCR pada sampel nyamuk di Kabupaten Jembrana, Propinsi Bali menunjukkan An. kochi dan An tesselatus positif mengandung $P$. falciparum. Distribusi penyebaran spesies Anopheles yang terkonfirmasi positif $P$. falciparum di berbagai ekosistem di Kabupaten Jembrana dapat dilihat pada Tabel 5.

Berdasarkan hasil penangkapan nyamuk di Kabupaten Bengkalis, Provinsi Riau menunjukkan bahwa An. sinensis, An. umbrosus, An. letifer, An. separatus, An. sundaicus tertangkap pada saat dikoleksi menggunakan umpan manusia. Spesies lain yang juga ditemukan dalam populasi rendah adalah An. vagus, An. tesselatus dan An. kochi. Penyebaran spesies Anopheles yang tertangkap di masing-masing ekosistem dapat dilihat pada Tabel 3. Berdasarkan perilaku menghisap darah diketahui bahwa An. sinensis dan An. sundaicus hasil koleksi 50\% menghisap darah manusia. Hasil penangkapan nyamuk juga diperoleh An. letifer seluruhnya terdeteksi menghisap darah manusia (Tabel 3). Fluktuasi kepadatan nyamuk Anopheles di Kabupaten Bengkalis Riau cenderung rendah pada masingmasing spesies pada setiap jam penangkapan. $A n$. umbrosus dilaporkan dengan kepadatan tinggi hanya pada awal jam penangkapan antara pukul 18.00-21.00. Gambaran fluktuasi kepadatan nyamuk dapat dilihat pada Gambar 2.

Berdasarkan hasil konfirmasi keberadaan Plasmodium dengan menggunakan PCR menunjukkan bahwa $A n$. sinensis positif mengandung $P$. falciparum. An. sinensis yang positif mengandung $P$. falciparum tersebut diketahui menghisap darah ternak. Distribusi penyebaran spesies An. sinensis di Kabupaten Bengkalis pada berbagai ekosistem dapat dilihat pada tabel 5 .

Hasil penangkapan nyamuk di Kabupaten Bulukumba Propinsi Sulawesi Selatan menunjukkan bahwa An. barbirostris, An. peditaeniatus, An. subpictus, An. tesselatus dan An. vagus ditemukan menghisap darah manusia dan hewan. Beberapa spesies Anopheles lain yang ditemukan adalah An. karwari, An. limosus, An. indefinitus, dan An. kochi. Secara keseluruhan distribusi penyebaran nyamuk Anopheles tertangkap dengan berbagai metode di berbagai ekosistem di Kabupaten Bulukumba dapat dilihat pada Tabel 4. Anopheles vagus dan An. peditaeniatus merupakan dua spesies yang paling dominan dan ditemukan di setiap jam penangkapan sepanjang malam di Bulukumba. Kisaran puncak kepadatan nyamuk An. vagus terjadi di antara jam 18.00- 24.00. Sedangkan An. peditaeniatus puncak kepadatan terjadi pada jam 18.00-22.00. Fluktuasi kepadatan nyamuk masing-masing spesies Anopheles tertangkap sepanjang malam dapat dilihat pada Gambar 3.

Hasil konfirmasi keberadaan Plasmodium dalam tubuh nyamuk Anopheles yang berasal dari kabupaten Bulukumba dengan menggunakan PCR menunjukkan bahwa An. barbirostris, An. vagus, dan An. peditaeniatus yang positif mengandung Plasmodium. Secara lengkap, distribusi spesies Anopheles yang positif Plasmodium di berbagai ekosistem dapat dilihat pada Tabel 5.

Tempat perkembangbiakan nyamuk Anopheles di Kabupaten Jembrana adalah sawah, lagun, kobakan, rawa air payau, rawa air tawar dan kolam. Di wilayah Kabupaten Bengkalis, tempat perkembangbiakan Anopheles yang berhasil diamati meliputi parit, kobakan, lagun, perahu, tempat perendaman karet, kobakan dan rawa air tawar. Sedangkan tempat perkembangbiak Anopheles yang ditemukan di Kabupaten Bulukumba meliputi cekungan batu, rembesan air, parit, kobakan, sawah, tambak dan kobakan. 
Tabel 2. Distribusi Anopheles tertangkap dengan berbagai metode di Kabupaten Jembrana Propinsi Bali 2017.

\begin{tabular}{|c|c|c|c|c|c|c|c|}
\hline \multirow{2}{*}{ Metode } & \multirow{2}{*}{ Spesies } & \multicolumn{6}{|c|}{ Ekosistem } \\
\hline & & HDP & HJP & NHDP & NHJP & PDP & PJP \\
\hline \multirow{2}{*}{ UOD } & Anopheles vagus & 0 & 0 & 0 & 0 & 2 & 0 \\
\hline & Anopheles tesselatus & 0 & 0 & 1 & 0 & 0 & 0 \\
\hline \multirow{8}{*}{ UOL } & Anopheles vagus & 0 & 0 & 1 & 11 & 0 & 1 \\
\hline & Anopheles barbumbrosus & 0 & 1 & 0 & 0 & 0 & 0 \\
\hline & Anopheles maculatus & 0 & 1 & 0 & 0 & 0 & 0 \\
\hline & Anopheles tesselatus & 0 & 0 & 1 & 0 & 0 & 0 \\
\hline & Anopheles barbirostris & 0 & 0 & 0 & 2 & 0 & 0 \\
\hline & Anopheles subpictus & 0 & 0 & 0 & 2 & 0 & 1 \\
\hline & Anopheles indefinitus & 0 & 0 & 0 & 0 & 1 & 0 \\
\hline & Anopheles sundaicus & 0 & 0 & 0 & 0 & 6 & 0 \\
\hline \multirow{7}{*}{$\mathrm{ABT}$} & Anopheles kochi & 1 & 0 & 4 & 0 & 13 & 0 \\
\hline & Anopheles vagus & 2 & 0 & 82 & 0 & 25 & 0 \\
\hline & Anopheles barbirostris & 0 & 0 & 4 & 0 & 4 & 0 \\
\hline & Anopheles indefinitus & 0 & 0 & 2 & 0 & 0 & 0 \\
\hline & Anopheles subpictus & 0 & 0 & 2 & 0 & 14 & 0 \\
\hline & Anopheles tesselatus & 0 & 0 & 3 & 0 & 2 & 0 \\
\hline & Anopheles sundaicus & 0 & 0 & 0 & 0 & 5 & 0 \\
\hline \multirow{8}{*}{ UT } & Anopheles kochi & 2 & 0 & 3 & 0 & 7 & 0 \\
\hline & Anopheles vagus & 6 & 0 & 243 & 0 & 64 & 0 \\
\hline & Anopheles barbirostris & 0 & 0 & 3 & 0 & 2 & 0 \\
\hline & Anopheles indefinitus & 0 & 0 & 21 & 0 & 0 & 0 \\
\hline & Anopheles subpictus & 0 & 0 & 13 & 0 & 3 & 0 \\
\hline & Anopheles tesselatus & 0 & 0 & 7 & 0 & 4 & 0 \\
\hline & Anopheles annularis & 0 & 0 & 0 & 0 & 1 & 0 \\
\hline & Anopheles sundaicus & 0 & 0 & 0 & 0 & 3 & 0 \\
\hline \multirow{3}{*}{ MR } & Anopheles vagus & 0 & 0 & 0 & 0 & 3 & 0 \\
\hline & Anopheles kochi & 0 & 0 & 0 & 4 & 0 & 0 \\
\hline & Anopheles subpictus & 0 & 0 & 0 & 0 & 1 & 0 \\
\hline
\end{tabular}

Keterangan:

Tidak ditemukan nyamuk Anopheles pada penangkapan dengan light trap

HDP : Hutan Dekat Pemukiman UOD : Umpan Orang Dalam

HJP : Hutan Jauh Pemukiman UOL : Umpan Orang Luar

NHDP: Non Hutan Dekat Pemukiman $\quad$ ABT : Animal Baited Trap

NHJP : Non Hutan Jauh Pemukiman UT : Umpan Ternak

PDP : Pantai Dekat Pemukiman MR : Morning Resting

PJP : Pantai Jauh Pemukiman

Tabel 3. Distribusi Anopheles tertangkap dengan berbagai metode di Kabupaten Bengkalis Propinsi Riau 2017

\begin{tabular}{|c|c|c|c|c|c|c|c|}
\hline \multirow{2}{*}{ Metode } & \multirow{2}{*}{ Spesies } & \multicolumn{6}{|c|}{ Ekosistem } \\
\hline & & HDP & HJP & NHDP & NHJP & PDP & PJP \\
\hline \multirow{5}{*}{ UOL } & Anopheles sinensis & 2 & 0 & 0 & 1 & 0 & 3 \\
\hline & Anopheles umbrosus & 1 & 82 & 0 & 1 & 0 & 1 \\
\hline & Anopheles letifer & 0 & 23 & 0 & 2 & 0 & 2 \\
\hline & Anopheles separatus & 0 & 1 & 0 & 14 & 0 & 4 \\
\hline & Anopheles sundaicus & 0 & 0 & 0 & 0 & 1 & 0 \\
\hline \multirow{6}{*}{$\mathrm{ABT}$} & Anopheles separatus & 15 & 0 & 0 & 0 & 0 & 0 \\
\hline & Anopheles sinensis & 3 & 0 & 0 & 0 & 0 & 0 \\
\hline & Anopheles umbrosus & 10 & 0 & 0 & 0 & 0 & 0 \\
\hline & Anopheles vagus & 5 & 0 & 0 & 0 & 0 & 0 \\
\hline & Anopheles sundaicus & 0 & 0 & 0 & 0 & 1 & 0 \\
\hline & Anopheles tesselatus & 0 & 0 & 0 & 0 & 1 & 0 \\
\hline
\end{tabular}




\begin{tabular}{clllllll} 
& Anopheles kochi & 2 & 0 & 0 & 0 & 0 & 0 \\
UT & Anopheles separatus & 2 & 0 & 0 & 0 & 0 & 0 \\
& Anopheles sinensis & 3 & 0 & 0 & 0 & 0 & 0 \\
& Anopheles umbrosus & 1 & 0 & 0 & 0 & 0 & 0 \\
\\
Anopheles vagus & 3 & 0 & 0 & 0 & 0 & 0 \\
\hline
\end{tabular}

Keterangan:

HDP : Hutan Dekat Pemukiman

HJP : Hutan Jauh Pemukiman

UOD : Umpan Orang Dalam

NHDP: Non Hutan Dekat Pemukiman

UOL : Umpan Orang Luar

NHJP : Non Hutan Jauh Pemukiman

ABT : Animal Baited Trap

PDP : Pantai Dekat Pemukiman

UT : Umpan Ternak

MR : Morning Resting

Tabel 4. Distribusi Anopheles tertangkap dengan berbagai metode di Kabupaten Bulukumba Propinsi Sulawesi Selatan 2017

\begin{tabular}{|c|c|c|c|c|c|c|c|}
\hline \multirow{2}{*}{ Metode } & \multirow{2}{*}{ Spesies } & \multicolumn{6}{|c|}{ Ekosistem } \\
\hline & & HDP & HJP & NHDP & NHJP & PDP & PJP \\
\hline \multirow{2}{*}{ UOD } & Anopheles barbirostris & 4 & 0 & 0 & 0 & 0 & 0 \\
\hline & Anopheles peditaeniatus & 0 & 0 & 1 & 0 & 0 & 0 \\
\hline \multirow{7}{*}{ UOL } & Anopheles barbirostris & 9 & 5 & 0 & 88 & 0 & 0 \\
\hline & Anopheles karwari & 0 & 0 & 0 & 7 & 0 & 0 \\
\hline & Anopheles limosus & 0 & 0 & 0 & 2 & 0 & 0 \\
\hline & Anopheles peditaeniatus & 0 & 1 & 1 & 335 & 0 & 0 \\
\hline & Anopheles subpictus & 0 & 0 & 0 & 0 & 0 & 1 \\
\hline & Anopheles tesselatus & 0 & 1 & 0 & 1 & 0 & 0 \\
\hline & Anopheles vagus & 0 & 11 & 2 & 3 & 0 & 0 \\
\hline \multirow{8}{*}{$\mathrm{ABT}$} & Anopheles barbirostris & 14 & 7 & 1 & 1 & 0 & 0 \\
\hline & Anopheles indefinitus & 0 & 0 & 0 & 0 & 0 & 3 \\
\hline & Anopheles kochi & 0 & 0 & 2 & 0 & 0 & 0 \\
\hline & Anopheles limosus & 0 & 0 & 8 & 0 & 0 & 0 \\
\hline & Anopheles peditaeniatus & 22 & 0 & 33 & 16 & 0 & 0 \\
\hline & Anopheles subpictus & 0 & 0 & 0 & 0 & 1 & 43 \\
\hline & Anopheles tesselatus & 0 & 0 & 3 & 0 & 0 & 0 \\
\hline & Anopheles vagus & 3 & 9 & 415 & 0 & 77 & 2 \\
\hline \multirow{3}{*}{ UT } & Anopheles barbirostris & 3 & 0 & 2 & 0 & 0 & 0 \\
\hline & Anopheles peditaeniatus & 0 & 0 & 3 & 0 & 0 & 0 \\
\hline & Anopheles vagus & 0 & 0 & 37 & 0 & 7 & 0 \\
\hline \multirow{2}{*}{ MR } & Anopheles barbirostris & 2 & 0 & 0 & 3 & 0 & 0 \\
\hline & Anopheles peditaeniatus & 0 & 0 & 0 & 3 & 0 & 0 \\
\hline
\end{tabular}

Keterangan:

Tidak ditemukan nyamuk Anopheles pada penangkapan dengan light trap

HDP : Hutan Dekat Pemukiman UOD : Umpan Orang Dalam

HJP : Hutan Jauh Pemukiman UOL : Umpan Orang Luar

NHDP: Non Hutan Dekat Pemukiman $\quad$ ABT : Animal Baited Trap

NHJP : Non Hutan Jauh Pemukiman UT : Umpan Ternak

PDP : Pantai Dekat Pemukiman MR : Morning Resting

PJP : Pantai Jauh Pemukiman

Tabel 5. Distribusi Anopheles yang terkonfirmasi positif Plasmodium falciparum di Kabupaten Jembrana, Kabupaten Bengkalis dan Kabupaten Bulukumba 2017

\begin{tabular}{|c|c|c|c|c|c|c|c|c|c|}
\hline \multirow{2}{*}{ Provinsi } & \multirow{2}{*}{ Kabupaten } & \multirow{2}{*}{ Spesies } & \multicolumn{6}{|c|}{ Ekosistem } & \multirow{2}{*}{ Metode yang digunakan } \\
\hline & & & HDP & HJP & NHDP & NHJP & PDP & PJP & \\
\hline Bali & Jembrana & $\begin{array}{l}\text { Anopheles kochi } \\
\text { Anopheles tesselatus }\end{array}$ & & & ++ & & + & & $\begin{array}{l}\text { Metode ABT dan UT } \\
\text { Metode UT }\end{array}$ \\
\hline Sulawesi selatan & Bulikumba & $\begin{array}{l}\text { Anopheles barbirostris } \\
\text { Anopheles vagus } \\
\text { Anopheles peditaeniatus }\end{array}$ & ++ & + & + & & + & & $\begin{array}{l}\text { Metode UT, ABT } \\
\text { Metode ABT, ABT } \\
\text { Metode ABT }\end{array}$ \\
\hline Riau & Bengkalis & Anopheles sinensis & + & & & & & & Metode UT \\
\hline
\end{tabular}


Keterangan:

HDP : Hutan Dekat Pemukiman

HJP : Hutan Jauh Pemukiman

NHDP : Non Hutan Dekat Pemukiman

NHJP : Non Hutan Jauh Pemukiman

PDP : Pantai Dekat Pemukiman

PJP : Pantai Jauh Pemukiman

$+\quad$ : Positif P. falciparum di satu metode penangkapan

$+\quad$ : Positif $P$. falciparum di dua metode penangkapan

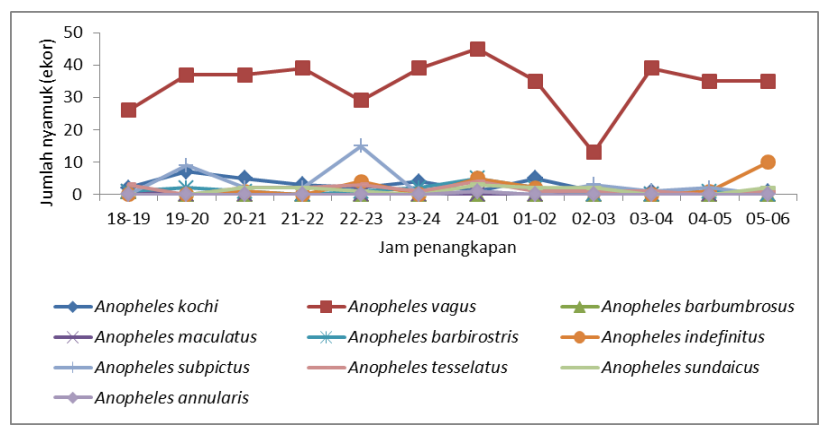

Gambar 1. Fluktuasi kepadatan nyamuk Anopheles di Kabupaten Jembrana Bali 2017.

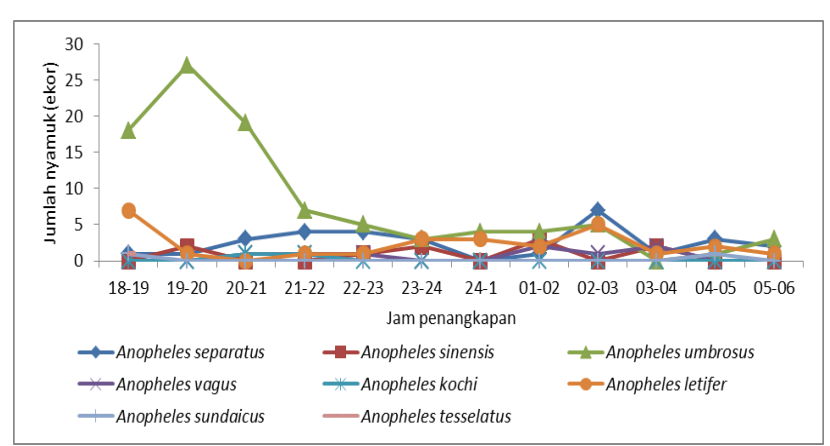

Gambar 2. Fluktuasi kepadatan nyamuk Anopheles di Kabupaten Bengkalis Riau 2017.

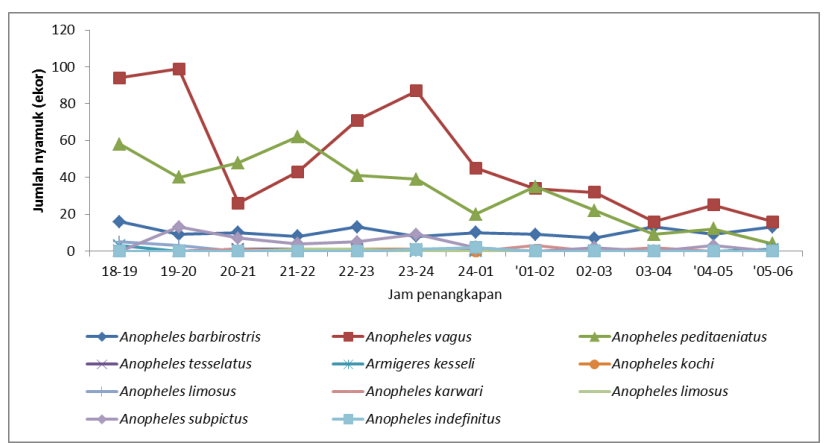

Gambar 3. Fluktuasi kepadatan nyamuk Anopheles di Kabupaten Bulukumba Sulawesi Selatan 2017.

\section{PEMBAHASAN}

Hasil koleksi terhadap nyamuk Anopheles yang menunjukkan bahwa Anopheles tesselatus dan An. kochi positif ditemukan mengandung Plasmodium falciparum. Hal ini merupakan catatan baru terkait keberadaan $P$. falciparum pada kedua spesies Anopheles tersebut di Provinsi Bali. Anopheles kochi juga telah terkonfirmasi positif P.falciparum pada penelitian sebelumnya di Pulau Nias, Jawa, dan Sulawesi. Deteksi circum sprorozoit $P$. vivax ditemukan di Jawa sedangkan di Sulawesi di temukan $P$. vivax dan $P$. falciparum. ${ }^{16}$

Dari studi yang telah dilakukan pada saat Bali masih menjadi daerah endemis malaria beberapa dekade yang lalu, spesies yang terkonfirmasi sebagai vektor malaria di Bali meliputi An. aconitus, An. sundaicus, dan An. maculatus. ${ }^{5}$ An. kochi yang terdeteksi positif mengandung $P$. falciparum berhasil dikoleksi dari ekosistem non-hutan dekat pemukiman, sedangkan An. tesselatus yang positif dengan P. falciparum berasal dari koleksi di wilayah ekosistem pantai dekat pemukiman.

Keberadaan kedua spesies Anopheles positif $P$. falciparum cukup mendapat perhatian. Hal ini dikarenakan Bali merupakan provinsi yang telah mendapatkan sertifikat eliminasi malaria. Meskipun masih dijumpai kasus malaria dalam dua tahun terakhir (API sebesar 0,0003\%o pada tahun 2015 dan 0,0024\% pada tahun 2016), namun seluruhnya merupakan kasus import dan tidak dilaporkan adanya kasus indigenous (setempat). Tindak lanjut kegiatan surveilans vektor di lokasi tempat ditemukannya nyamuk Anopheles positif Plasmodium dalam studi ini diperlukan untuk memastikan apakah Anopheles yang positif tersebut mendapatkan parasit $P$. falciparum dari kasus import ataukah memang sudah terjadi transmisi secara lokal (indigenous) di wilayah tersebut.

Hasil uji pakan darah terhadap $A n$. kochi juga mengungkapkan bahwa 100\% dari sampel yang diperiksa menghisap darah ternak. Meskipun demikian, potensi sebagai vektor penular penyakit dimungkinkan, baik pada nyamuk yang cenderung menghisap darah manusia maupun hewan. Beberapa studi juga menyebutkan bahwa terdapat kecenderungan spesies tersebut menghisap darah hewan daripada manusia. Anopheles kochi di Jawa Barat dan Timur juga dominasi ditemukan di kandang ternak, 15\% menghisap darah manusia dengan persentase 2,8\% menghisap darah manusia di dalam rumah. ${ }^{16}$ Anopheles kochi di Sumatera ditemukan menghisap darah manusia baik di 
dalam dan luar rumah. ${ }^{16}$

Hasil uji pakan darah terhadap $A n$. tesselatus di Kabupaten Jembrana menunjukkan bahwa $12,5 \%$ dari sampel nyamuk yang diuji, positif mengandung darah manusia dan kurang lebih $87,5 \%$ nyamuk yang tertangkap ditemukan menghisap darah hewan. Anopheles tesselatus sebelumnya pernah dilaporkan sebagai vektor malaria di Sumatera. ${ }^{5}$

Berdasarkan hasil koleksi di lapangan, An. vagus merupakan spesies yang paling dominan ditemukan. Spesies ini ditemukan setiap jam dengan puncak kepadatan terjadi pada dini hari pada pukul $05.00-06.00$. Studi sebelumnya menyebutkan bahwa peningkatan populasi An. vagus dipengaruhi oleh curah hujan. Musim berpengaruh terhadap peluang tersedianya tempat yang berpotensi sebagai tempat perkembangbiakan nyamuk. Pada curah hujan yang cukup memungkinkan terbentuk tempat perkembangbiakan nyamuk, akan tetapi curah hujan yang tinggi dapat menyebabkan populasi nyamuk menurun akibat tempat perkembangbiakan mengalami banjir. ${ }^{17}$ Adapun jenis tempat perkembangbiakan An. vagus yang ditemukan meliputi sawah, kobakan dan tempurung kelapa. Penelitian sebelumnya di Lombok Tengah menyebutkan bahwa tempat perkembangbiakan An. vagus selain ditemukan di sawah juga ditemukan di parit, selokan, dan genangan air. ${ }^{18}$

Anopheles vagus pernah terkonfirmasi sebagai vektor malaria di beberapa lokasi di Indonesia, antara lain Jawa Tengah dan NTT. ${ }^{5}$ DI Kulon Progo, Provinsi DIY, An vagus di juga pernah terkonfirmasi positif mengandung $P$. falciparum berdasarkan pemeriksaan circum sporozoit protein (CSP) dengan menggunakan ELISA. ${ }^{19}$ Anopheles vagus juga pernah dilaporkan terkofirmasi sebagai vektor malaria di beberapa negara di Asia. Di Bangladesh, An. vagus pernah terkonfirmasi positif membawa $P$. falciparum dan $P$. vivax. Anopheles vagus juga telah terkonfirmasi sebagai vektor malaria di India dan cenderung bersifat zoophilic, exophilic dan exophagic walaupun pernah ditemukan menghisap darah manusia. ${ }^{20}$ Beberapa negara lain di Asia yang juga melaporkan An. vagus sebagai vektor malaria adalah Cambodia, China, Laos, Malaysia, Myanmar, Nepal, Philipina, Srilanka, Thailand, dan Vietnam. Spesies ini ditemukan baik di dalam maupun di luar rumah. . $1,22,23,24^{2}$

Di Kabupaten Bulukumba, An. barbirostris, An. vagus dan $A n$. peditaeniatus positif terdeteksi positif mengandung $P$. falciparum. Nyamuk ini ditemukan tersebar baik di daerah dekat pemukiman maupun jauh pemukiman. An. barbirostris terdeteksi positif $P$. falciparum di ekosistem HDP, An. vagus positif P. falciparum di HJP dan PDP, sedangkan An. peditaeniatus terdeteksi $P$. falciparum di NHDP. Meskipun kabupaten ini juga telah mendapatkan sertifikat eliminasi, namun hasil ini mengindikasikan bahwa di ekosistem baik hutan, non hutan maupun pantai masih berpotensi terjadi penularan malaria kembali. $^{25,26}$

Beberapa faktor yang mempengaruhi transmisi patogen antara lain faktor biologi dan faktor lingkungan. Salah satu faktor biologi adalah keberadaan vektor dan ketahanan nyamuk terhadap patogen. Keberadaan vektor salah satunya dapat dilihat dari populasinya di alam. Semakin tinggi populasi vektor di alam akan memperbesar peluang terjadinya penularan. Potensi ini akan semakin bertambah dengan umur nyamuk yang panjang. Kemampuan bertahan hidup vektor di alam akan memberikan kesempatan Plasmodium untuk berkembangbiak sebelum ditularkan ke manusia. ${ }^{27}$ Potensi penularan malaria di Kabupaten Bulukumba juga didukung oleh tingginya populasi spesies Anopheles yang terduga sebagai vektor tersebut. Secara umum An. barbirostris, An. vagus, dan An. peditaeniatus merupakan tiga spesies nyamuk yang memiliki populasi yang lebih tinggi jika dibandingkan spesies Anopheles lain di Kabupaten Bulukumba. ${ }^{27}$

Hasil studi Anopheles yang telah dilakukan di Kabupaten Bengkalis menunjukkan bahwa An. sinensis diidentifikasi positif mengandung $P$. falciparum dengan pemeriksaan PCR di ekosistem hutan dekat pemukiman. Meskipun populasi spesies ini cukup rendah selama koleksi nyamuk berlangsung, akan tetapi perlu diwaspadai potensinya sebagai vektor munculnya malaria kembali di wilayah tersebut. Potensi $A n$. sinensis sebagai vektor malaria juga didukung hasil analisis pakan darah yang menunjukkan $50 \%$ An. sinensis dari total nyamuk dalam spesies ini menghisap darah manusia dan 50\% menghisap darah hewan. Hasil studi sebelumnnya An. sinensis juga telah terkonfirmasi sebagai vektor malaria di Lampung, Aceh, Sumatera Barat, Riau, Jambi, Sumatera Selatan, dan Bengkulu. ${ }^{5,36}$ Anopheles sinensis juga telah terkonfirmasi sebagai vektor malaria di China walaupun bukan vektor utama karena bersifat zoofilik. Jenis Plasmodium yang ditemukan di An. sinensis adalah Plasmodium 
vivax. Spesies ini diketahui menghisap darah dan istirahat di luar rumah. ${ }^{37,38}$

Beberapa spesies nyamuk yang juga ditemukan di Riau yang sebelumnya juga diketahui sebagai vektor malaria adalah $A n$. letifer dan An. sundaicus. ${ }^{5}$ An letifer berdasarkan hasil penangkapan ditemukan hanya menghisap darah manusia. Kecederungan menghisap darah manusia ini juga memperbesar peluang An. letifer berperan sebagai vektor malaria. Berdasarkan studi sebelumnya An. letifer juga telah terkonfirmasi sebagai vektor malaria di Sumatera Utara, Jambi, Sumatera Selatan, Kepulauan Riau, Kalimantan Barat, Kalimantan Tengah, Kalimantan Selatan, dan Kalimantan Timur. ${ }^{5}$ Anopheles sundaicus sebelumnya telah terkonfirmasi sebagai vektor malaria di Jawa Tengah, Jawa Barat, DIY Yogyakarta, Jawa Timur, DKI Jakarta, Bali, Lampung, Aceh, Sumatera Utara, Sumatera Barat, Riau, Jambi, Sumatera Selatan, Sulawesi Selatan, NTT, dan Bengkulu. Studi di Pulau Sebatik Anopheles sundaicus terkonfirmasi positif P.falciparum yang ditemukan menghisap darah orang di luar rumah. Hal ini mengindikasikan bahwa proses penularan malaria terjadi di luar rumah. Sehingga proteksi diri sangat diperlukan ketika beraktivitas malam hari di luar rumah. ${ }^{39,40}$

Sehubungan dengan hasil konfirmasi terhadap beberapa spesies Anopheles yang ditemukan positif mengandung Plasmodium, perlu dilakukan upaya surveilans secara aktif dan pengendalian vektor di daerah yang rawan terjadinya penularan malaria kembali di daerah yang telah mendapatkan sertifikat eliminasi. Kegiatan pengendalian vektor seharusnya didasarkan pada data entomologi yang tepat agar pengendalian tepat sasaran. Hasil ratarata penangkapan nyamuk ditemukan nyamuk berpotensi sebagai vektor malaria ditemukan menghisap darah orang baik di dalam dan luar rumah. Berdasarkan data tersebut, program pengendalian vektor yang selama ini telah dilakukan, yaitu dengan indoor residual spraying (IRS) dan kelambu berinsektisida masih relevan dilakukan. ${ }^{28,29}$ Penggunaan kelambu dan IRS di Afrika juga dapat menurunkan kasus malaria. ${ }^{30} \mathrm{Hal}$ yang perlu diperhatikan dalam pengendalian vektor antara lain cakupan aplikasi IRS dan kelambu di daerah pengendalian. ${ }^{31,32}$ Efektivitas pengendalian dengan kelambu dipengaruhi oleh lama penggunaan, dan frekuensi pencucian kelambu dan spesies vektor yang dikendalikan. Efektivitas kelambu juga dipengaruhi oleh proses pengeringan ketika di cuci. Pengeringan kelambu setelah dicuci disarankan dikeringkan dengan cara mengangin-anginkan tidak dibawah sinar matahari langsung, karena proses pemanasan dapat menyebabkan insektisida di dalam kelambu mengalami degradasi yang berakibat pada penurunan efektivitas kelambu dalam membunuh nyamuk vektor. ${ }^{33}$ Tidak efektifnya kelambu dalam pengendalian vektor juga dapat disebabkan oleh resistensi vektor yang dikendalikan. ${ }^{34,35}$

Berdasarkan hasil survei menunjukkan bahwa Kabupaten Jembrana, Bulukumba dan Bengkalis yang telah mendapatkan sertifikat eliminasi malaria masih merupakan daerah reseptif dan berpotensi terjadinya penularan malaria kembali apabila tidak dilakukan surveilans vektor dan surveilans migrasi untuk mengidentifikasi kasus import secara aktif. Peraturan Menteri Kesehatan Nomor 293/ Menkes/SK/IV/2009 tentang eliminasi malaria di Indonesia mengamanatkan beberapa langkah dalam rangka mempertahankan daerah eliminasi malaria, diantaranya adalah mempertahankan kasus indigenous tetap nol dan tetap melaksanakan kegiatan surveilans. Kegiatan surveilans vektor diperlukan untuk mengetahui keberadaan spesies yang berpotensi sebagai vektor malaria dalam antisipasi pengendalian vektor. ${ }^{1}$

\section{KESIMPULAN}

Kabupaten Jembrana, Bengkalis dan Bulukumba merupakan daerah reseptif terhadap potensi penularan malaria kembali walaupun merupakan daerah yang telah mendapatkan sertifikat eliminasi malaria karena masih ditemukan Anopheles yang potensial sebagai vektor dan Plasmodium falciparum yang berhasil dikonfirmasi dari beberapa spesies Anopheles di lokasi tersebut. Surveilans vektor dan implementasi pengendalian vektor yang tepat serta surveilans migrasi secara ketat diperlukan untuk memastikan apakah Anopheles yang positif tersebut mendapatkan parasit $P$. falciparum dari kasus import ataukah memang sudah terjadi transmisi secara lokal (indigenous) di wilayah tersebut. Hal ini perlu dilakukan agar tidak terjadi penularan kembali malaria di daerah yang sudah tereliminasi tersebut.

\section{UCAPAN TERIMA KASIH}

Dalam proses penulisan artikel ini tak lupa penulis mengucapkan terimksih kepada 
Kepala B2P2VRP Salatiga Bapak Joko Waluyo, BSc., ST., Dipl.EIA., MSc.PH dan Bapak DR Ristiyanto selaku penanggung jawab Riset Khusus Vektora 2017. Dra Widiarti, M.Kes sebagai ketua PPI. Tak lupa kami juga mengucapkan banyak terimkasih kepada PJT Rikhus Vektora Propinsi Bali, Riau dan Bulukumba, Tim Teknis Riset Kusus Vektora, Katim dan Wakatim Propinsi Bali, Riau dan Bulukumba serta segenap tim pengumpul data Rikhus Vektora 2017.

\section{DAFTAR RUJUKAN}

1. Kementerian Kesehatan RI. Keputusan Menteri Kesehatan Republik Indonesia no293/Menkes/ SK/IV/2009. Jakarta; 2009. 1-36 p.

2. Kemenkes RI DiP. Panduan Pemeliharaan Eliminasi Malaria. Panduan Pemeliharaan Eliminasi Malaria. Jakarta: P2PTVZ; 2017. $1-28 \mathrm{p}$.

3. P2PTVZ. Data Kasus Malaria 2012-2017. Jakarta: P2PTVZ; 2017.

4. Burkot TR, Farlow R, Min M, Espino E, Mnzava A, Russell TL. A global analysis of national malaria control programme vector surveillance by elimination and control status in 2018. Malar J. 2019;18(1):399.

5. B2P2VRP. Pedoman Pengumpulan Data Vektor (Nyamuk) di Lapangan. Salatiga; 2017.

6. Badan Penelitian dan Pengembangan Kesehatan Kementrian Kesehatan Republik Indonesia. Laporan Akhir Riset Khusus Vektor dan Reservoir Penyakit Provinsi Bali. Salatiga: B2P2VRP; 2017. 1-76 p.

7. Badan Penelitian dan Pengembangan Kesehatan Kementrian Kesehatan Republik Indonesia. Laporan Akhir Riset Khusus Vektor dan Reservoir Penyakit Provinsi Riau Tahun 2017. Salatiga: B2P2VRP; 2017. 1-113 p.

8. Badan Penelitian dan Pengembangan Kesehatan Kementrian Kesehatan Republik Indonesia. Laporan Akhir Riset Khusus Vektor dan Reservoir Penyakit Provinsi Sulawesi Selatan. Salatiga: B2P2VRP; 2017. 1-105 p.

9. WHO. Manual on Pactical Entomology in Malaria. Geneva; 1975. 1-186 p.

10. Oconnor AS. Kunci Bergambar Nyamuk Anopheles Dewasa di Indonesia. Jakarta; 1999. $1-40 \mathrm{p}$.

11. Reid JA. Anopheline Mosquitoes of Malaya and Borneo. Malaysia; 1968. 1-520 p.

12. Panthusiri, Rattanarithikul R, Prachong. Illustrated Keys to the Medically Important
Mosquitoes of Thailand. Thailand; 1994. 1-66 $\mathrm{p}$.

13. B2P2VRP. Pedoman Pemeriksaan Deteksi agen Penyakit. Salatiga; 2015.

14. Singh B, Bobogare A, Cox-singh J, Snounou G, Abdullah MS, Rahman HA. A Genusand Spesies-Spesifik Nested Polymerase Chain Reaction Malaria Detection Assay for Epidemiologic Studies. Am Soc Trop Med Hyg. 1999;60(4):687-92.

15. Moll K, Kaneko A, Scherf A, Wahlgren M. Methods in Malaria Research. UK: EviMalaR Glasgow; 2013. 1-474 p.

16. Elyazar IRF, Sinka ME, Gething PW, Tarmidzi SN, Surya A, Kusriastuti R, et al. The Distribution and Bionomics of Anopheles malaria Vector Mosquitoes in Indonesia. 1st ed. Vol. 83, Advances in Parasitology. Elsevier Ltd.; 2013. 173-266 p.

17. Stoops CA, Rusmiarto S, Susapto D, Munif A, Andris H, Barbara KA, et al. Bionomics of Anopheles spp . ( Diptera : Culicidae ) in a Malaria Endemic Region of Sukabumi, West Java, Indonesia. J Vector Ecol. 2009;34(2):2007.

18. Mading M, Sopi IIP. Beberapa Aspek Bioekologi Nyamuk Anopheles vagus di Desa Selong Belanak Kabupaten Lombok Tengah. Spirakel [Internet]. 2014;6(1):26-32. Available from:http://ejournal.litbang.kemkes.go.id/ index.php/spirakel/article/view/6127.

19. Wigati RA, Mardiana M, Mujiyono M, Alfiah S. Deteksi Protein Circm Sporozoite pada Spesies Nyamuk Anophele vagus Tersangka Vektor Malaria di Kecamatan Kokap, Kabupaten Kulon Progo dengan Uji EnzymeLinked Immunosorbent Assay (ELISA). Media Litbang Kesehat. 2010;XX(3):118-23.

20. Dhiman S, Yadav K, Rabha B, Goswami D, Hazarika S, Tyagi V. Evaluation ofInsecticides Susceptibility and Malaria Vector Potential of Anopheles annularis s.l. and Anopheles vagus in Assam, India. PLoS One [Internet]. 2016;11(3):1-13. Available from: http://dx.doi. org/10.1371/journal.pone.0151786.

21. Alam Z, Arifin SMN, Mohammad H, Amin A, Alam MS, Rahman MS. A Spatial Agent Based Model of Anopheles vagus for Malaria Epidemiology: Examining the Impact of Vector Control Interventions. Malar J [Internet]. 2017;16(432):1-20. Available from: "http:// dx.doi.org/10.1186/s12936-017-2075-6.

22. Bashar K, Tuno N. Seasonal Abundance of Anopheles Mosquitoes andTheir Association 
with Meteorological Factors and Malaria Incidence in Bangladesh. Parasites and Vectors [Internet]. 2014;7(1):442.Available from:http:// www.ncbi.nlm.nih.gov/pubmed/25233890.

23. M RI, Pecor J E, A HB. Updated Distribution Records for Anopheles vagus (Diptera: Culicidae) in the Republic of Philippines, and Considerations Regarding Its Secondary Vector Roles in Southeast Asia. Trop Biomed. 2011;28(1):181-7.

24. Alam MS, Chakma S, Khan WA, Glass GE, MohonAN,ElahiR, etal.DiversityofAnopheline Species and Their Plasmodium Infection Status in Rural Bandarban, Bangladesh. Parasites and Vectors. 2012;5(150):1-9.

25. Kumar A, Hosmani R, Jadhav S, Sousa T De, Mohanty A, Naik M. Anopheles subpictus Carry Human Malaria Parasites in An Urban Area of Western India and May Facilitate Perennial Malaria Transmission. Malar J [Internet]. 2016;15(24):1-8. Available from: "http://dx.doi.org/10.1186/s12936-016-1177-x.

26. Alimi TO, Fuller DO, Qualls WA, Herrera S V, Arevalo-herrera M, Quinones ML, et al. Predicting Potential Ranges of Primary Malaria Vectors and malaria in northern South America Based on Projected Changes in Climate, Land Cover and Human Population. Parasit Vectors [Internet]. 2015;8(431):1-16. Available from: http://dx.doi.org/10.1186/s13071-015-1033-9.

27. Killeen GF. Characterizing, Controlling and Eliminating Residual Malaria Transmission. Malar J [Internet]. 2014;13(1):1-22. Available from:http://malariajournal.biomedcentral.com/ articles/10.1186/1475-2875-13-330.

28. Kemenkes RI. The Desk Review Malaria Programe Review 2016. Jakarta: Kemenkes RI; 2016. 1-74 p.

29. Killeen GF. Characterizing, Controlling and Eliminating Residual Malaria Transmission. Malar J. 2014;13(330):1-22.

30. Katureebe A, Zinszer K, Arinaitwe E, Rek J, Kakande E, Charland K, et al. Measures of Malaria Burden after Long- Lasting Insecticidal Net Distribution and Indoor Residual Spraying at Three Sites in Uganda : A Prospective Observational Study. PLoS Med [Internet]. 2016;8(December 2014):122. Available from:http://dx.doi.org/10.1371/ journal.pmed.1002167.

31. Husni, Rahayujati TB, Supargiyono S. Evaluasi Program Pencegahan dan Penanggulangan
Faktor Risiko Malaria di Kabupaten Kulon Progo. Ber Kedokt Masy. 2017;33(12):771-8.

32. World Health Organization. Malaria entomology and vector control. Vol. 3, World Health Organization. 2003. 1-109 p.

33. Kemenkes RI. Pedoman Penggunaan Kelambu Berinsektisida Menuju Eliminasi Malaria. 2011;

34. WHO. Test procedures for insecticide resistance monitoring in malaria vector mosquitoes Second edition. Geneva: Global Malaria Programme; 2016. 1-55 p.

35. WHO. Monitoring and managing insecticide resistance in Aedes mosquito populations Interim guidance for entomologists. Geneva: WHO; 2016. 1-13 p.

36. Taviv Y, Budiyanto A, Sitorus H, Ambarita LP, Mayasari R, Pahlepi RI. Sebaran Nyamuk Anopheles Pada Topografi Wilayah yang Berbeda di Propinsi Jambi. Media Litbangkes. 2015;25(2):1-8.

37. Ren Z, Wang D, Hwang J, Bennett A, Hugh J. Spatial-Temporal Variation and Primary Ecological Drivers of Anopheles sinensis Human Biting Rates in Malaria EpidemicProne Regions of China. PLoS One [Internet]. 2015;22(Januari):1-17. Available from: http:// dx.doi.org/10.1371/journal.pone.0116932.

38. Ren Z, Wang D, Hwang J, Bennett A, Sturrock HJW, Ma A, et al. Spatial-temporal Variation and Primary Ecological Drivers of Anopheles sinensis Human Biting Rates in Malaria Epidemic-prone Regions of China. PLoS One [Internet]. 2015;10(1):1-17. Available from:http://dx.doi.org/10.1371/journal. pone.0116932.

39. Sugiarto, Hadi UK, Soviana S, Hakim L. Confirmation of Anopheles peditaeniatus and Anopheles sundaicus as Malaria Vectors (Diptera: Culicidae) in Sungai Nyamuk Village, Sebatik Island North Kalimantan, Indonesia Using an Enzyme-linked Immunosorbent Assay. J Med Entomol. 2016;53(6):1422-4.

40. Nixon CP, Nixon CE, Arsyad DS, Chand K, Yudhaputri F a., Sumarto W, et al. Distance to Anopheles sundaicus Larval Habitats Dominant Among Risk Factors for Parasitemia in Mesoendemic Southwest Sumba, Indonesia. Pathog Glob Health [Internet]. 2014;108(8):369-80. Available from: http://www.tandfonline.com/ doi/full/10.1179/2047773214Y.0000000167. 